\title{
The welfare cost of terrorism
}

Margarita Vorsina ${ }^{1}$ - Matthew Manning ${ }^{2}$ - Christopher M. Fleming ${ }^{1 *}$ Christopher L. Ambrey ${ }^{3}$ - Christine Smith ${ }^{1}$

${ }^{1}$ Department of Accounting, Finance and Economics, Griffith University, Nathan, Queensland 4111, AUSTRALIA

${ }^{2}$ Centre for Aboriginal Economic Policy Research, The Australian National University, Canberra, Australian Capital Territory 2601, AUSTRALIA

${ }^{3}$ Urban Research Program, Griffith University, Gold Coast, Queensland 4222, AUSTRALIA

* Corresponding author: chris.fleming@griffith.edu.au 


\begin{abstract}
Data from 117 countries over the period 2006 to 2011 are used to estimate a macroeconomic cross-country system of equations that examines the association between terrorism, self-reported life satisfaction and national income. Results indicate that terrorism is negatively associated with life satisfaction, whereas no such association is found between terrorism and real GDP per worker. Stark contrasts are found, however, between OECD and non-OECD members. In all, our results suggest that the social costs of terrorism are potentially much higher than the economic costs, and measuring only the conventional economic costs of terrorism significantly underestimates the true costs.
\end{abstract}

Keywords: Subjective wellbeing, Life satisfaction, Terrorism

JEL codes: $\mathrm{I} 31, \mathrm{H} 56$, 


\section{Introduction}

Terrorism is an enduring consequence of the willingness of humans to use violence with the goal of affecting politics or forcefully promoting ones ideology by inducing fear in the populace. Such use of violence dates back, for example, to the Sicarii, a $1^{\text {st }}$ century Jewish group who murdered enemies and collaborators in their campaign to remove their Roman rulers from Judea. ${ }^{1}$ The more modern notion of terrorism, believed to be derived from Maxmilien Robespierre, follows the French revolution of the late 18th Century. Robespierre was the leader of a Committee of Public Safety, elected by the National Convention. A form of state terrorism, the committee enforced a reign of terror with the goal of expatiating democracy. According to Cobban:

[Robespierre's] view [was that] the people resorted to direct action for the purpose of protecting the principles of the Revolution by intimidating its enemies. This was only another way of saying that France was undergoing a revolution, in which intimidation was necessarily a part. Direct popular action, in fact, was another word for terrorism. ${ }^{2}$

The 20th Century saw a rise in ethnic nationalism with an increase in the use of guerrilla tactics by non-state actors such as the Castilians in Basque, ${ }^{3}$ the Irish Republican Army ${ }^{4}$ and various anti-colonial movements in British, French and German colonies in Africa. ${ }^{5}$ Many of these groups agitated for self-rule in order to break away from what they saw as an oppressive state (e.g., Nelson Mandela's African National Congress). They were, however, at that time viewed as terrorist groups. Terrorism as we know it in modern times is defined by acts such as the hijacking of the El AL Israel jet by the Popular Front for the Liberation of Palestine ${ }^{6}$ and the kidnapping and murder of Israeli athletes at the 1972 Olympic games. ${ }^{7}$ 
The 1990s saw an increase and escalation in religiously inspired groups (e.g., Al Qaeda, Hamas and Hezbollah) employing violent terrorist tactics to achieve their goals, the most notable being the attack on the World Trade Centre in New York on September 11, $2001(9 / 11) .^{8}$ More recent terror events include the kidnapping of Nigerian school girls by Islamist terror group Boko Haram, and the activities of the Islamic State of Iraq and the Levant (ISIL), who aim to create a caliphate or Islamic state in the Middle East. ${ }^{9}$

Alarmingly, the frequency of terror attacks appears to be increasing (see Figure 1). For example, the 2012 Global Terrorism Index Report notes that between 2002 and 2011 the total number of terrorist incidents increased by $464 \%{ }^{10}$ Further, the Institute's most recent Global Peace Index Report notes that terrorist activity (a composite weighted measure of the number of fatalities, injuries and property damage caused by terrorism) is one of the four indicators that recorded the greatest deterioration over the period 2008 to 2014. ${ }^{11}$ Between 2013 and 2014, terrorist activity recorded the greatest deterioration of all the Global Peace Index indicators, declining by $10 \%$, more than double the change of the next largest deteriorating indicator (the number of external and internal conflicts fought).

'Figure 1 here'

In the context of increased terrorist activity, there is a growing body of literature that examines the macroeconomic cost of terrorism. ${ }^{12}$ Our study takes a somewhat different approach to estimating the cost of terrorism - we measure the cost in terms of lower levels of life satisfaction. Specifically, we employ data from 117 countries over the period 2006 to 2011 to estimate a macroeconomic cross-country system of equations that examines the association between terrorism, self-reported life satisfaction and national income. This approach allows the welfare cost of terrorism to 
be expressed in life satisfaction terms and allows two effects to be estimated. First, the effect of terrorism on life satisfaction and second, the effect of terrorism on national income, which in turn effects life satisfaction (the 'direct' and 'indirect' effects respectively).

This paper extends the existing body of literature by: (1) demonstrating that, in addition to conventional objective measures such as per capita Gross Domestic Product (GDP), subjective measures of well-being should also be taken into account when evaluating the effects of terrorism; (2) estimating the link between life satisfaction and terrorism using a large cross-national sample (to the best of our knowledge previous studies of life satisfaction and terrorism have only focused on a single country or region); and (3) estimating both the direct effect of terrorism on life satisfaction as well as the indirect effect of terrorism on life satisfaction via its effect on national income - existing studies only focus on the former.

The paper proceeds by first discussing the literature with respect to the economic and psychological effects of terrorism. The empirical strategy is then outlined, followed by the data and variables employed. Results are presented and, finally, discussed.

\section{Related Literature}

\section{The Economic Effects of Terrorism}

A significant body of literature considers the cross-country macroeconomic effects of terrorism, in particular the effect of terrorism on GDP, national consumption, national investment, stock markets, Foreign Direct Investment (FDI) and foreign trade. For example, Blomberg find that, on average, terrorism significantly reduces per capita growth in GDP. ${ }^{13}$ The negative association between terrorism and economic growth, however, is small and statistically insignificant for 
Organisation for Economic Cooperation and Development (OECD) member countries. Tavares also finds that terrorism has an immediate negative impact on economic growth. ${ }^{14}$ However, when controlling for additional determinants of growth (for example, trade openness, the inflation rate, educational spending) the effect of terrorism becomes insignificant. More recently, Gaibulloev and Sandler find that international terrorism has a negative and significant effect on per capita income growth in Western European countries, African countries and developing countries in Asia. ${ }^{15}$ Domestic terrorism, in contrast, has a lower effect than international terrorism in Western European countries, while no impact is found in African countries. At a microeconomic level, Abadie and Gardeazabal estimate that per capita GDP in the Basque country of Spain decreased by more than $10 \%$ due to the terrorist attacks that occurred between 1975 and 1995. ${ }^{16}$ Similarly, Eckstein and Tsiddon show that terrorist attacks reduced Israel's per capita GDP by $10 \%$ to $15 \%$ during the initial period of the Palestinian Al-Aqsa. ${ }^{17}$

In regards to national consumption, the empirical evidence is mixed. Fielding suggests that terrorism in Israel leads to an increase in savings and a concomitant decrease in consumption. ${ }^{18}$ In contrast, Eckstein and Tsiddon find a negative association between terrorism and consumption in Israel, noting that a continued level of terrorism will lead to a decrease in per capita annual consumption by about five percent. ${ }^{19}$ These contrasting findings may be explained by the fact that consumption may be affected by terrorist activity in different ways. On the one hand, political violence might increase perceived risks associated with savings, either because legal claims on assets are compromised or because individuals are prevented from accessing their financial assets. On the other hand, terrorism may induce individuals to place their money in safe havens rather than buy, for example, durable consumer 
goods. The two effects point in opposite directions; how consumption is affected by terrorism is, therefore, ultimately an empirical question that remains to be answered. ${ }^{20}$

As noted by Frey et al., the effect of terrorism on aggregate consumption and savings is important as it influences the level of investment. ${ }^{21}$ One can also hypothesize that political violence not only affects the level, but also the composition, of investments. ${ }^{22}$ Fielding investigates the impact of political instability on the level and composition of investments in Israel. ${ }^{23}$ The indicators of political instability are the number of Israelis killed, the number of Palestinians killed, and the rate of growth of the Jewish settlements in the West Bank and Gaza areas. The author finds that both the number of Israelis killed and the rate of growth of Jewish settlements have a significantly negative impact on investment in non-residential construction. Manufacturing and equipment investment, however, is significantly lowered by an increase in the total number of deaths and the rate of growth of settlements.

Terrorist attacks are also found to have an impact on stock markets. Stock prices reflect expected future gains of a company, as well as the likelihood that these expected gains materialise - terrorist attacks influence both. ${ }^{24}$ Abadie and Gardeazabal find that stocks of firms with a significant part of their business in the Basque Country of Spain show a positive relative performance when a truce between the Basque separatists Euskadi Ta Askatasuna (ETA) and the Spanish state became credible, and a negative relative performance at the end of the ceasefire. ${ }^{25}$ Eldor and Melnik find that the number of suicide attacks had a permanent effect on Israel's stock and foreign exchange markets, as did the numbers of victims, while location of a terror attack had no effect on either market. ${ }^{26}$ In a cross-country study of 22 countries, Drakos finds that terrorist activity leads to significantly lower returns on the day a terrorist attack occurs, and that the negative effect of terrorist activity is substantially amplified when 
terrorist incidents cause higher psychosocial impact. ${ }^{27}$ Most recently, Essaddam and Karagianis focus on the stock return volatility of American firms targeted by terrorist attacks. ${ }^{28}$ The authors find that terrorism risk is an important factor in explaining the volatility of stock returns, which should be taken into account when modelling volatility. Specifically, the authors find that volatility increases on the day of the attack and remains significant for at least fifteen days thereafter. Further, their analysis indicates that the impact of terrorist attacks differs according to the country characteristics in which the incident occurred. That is, firms operating in wealthier, or more democratic countries, face greater volatility in stock returns relative to firms operating in developing countries.

In regards to FDI, Enders and Sandler estimate that terrorism in Spain reduced average annual FDI inflow by $13.5 \%$ over the period 1975 to $1991 .^{29}$ Similarly, terrorism in Greece reduced FDI by 11.9\% per annum over the period 1976 to 1991. These reductions in FDI are likely due to the fact that terrorism affects the allocation decision of firms investing money in real foreign assets. Terrorists can quite easily attack and damage foreign-owned firms, seriously disrupting their activities. As foreigners have a large choice of countries to invest in, even quite mild terrorist activity tends to considerably reduce the inflow of capital to a terror-stricken country. ${ }^{30}$

Terrorist activities can also affect foreign trade in several ways. First, the costs of doing business are raised by a general increase in insecurity as a result of terrorism. Second, augmented security measures in response to a terrorist campaign increase transaction costs. Third, there is the risk of a direct destruction of traded goods. Empirical evidence includes a study by Nitsch and Schumacher who show that terrorism has a negative association with foreign trade. ${ }^{31}$ Specifically, the authors find 
that countries that are targeted by terrorism trade less with each other than countries that are not targeted. Similarly, Mirza and Verdier reveal the negative effect of terrorism on trade, suggesting that a terrorist incident is associated with a $5.1 \%$ decline in bilateral trade. ${ }^{32}$ Further, in many countries, one of the largest export industries is the tourism industry; this is particularly vulnerable to terrorism. ${ }^{33}$

\section{The Psychological Effects of Terrorism}

Several studies estimate the effect of terrorist attacks on psychological and emotional states. For example, Salguero et al. analyse 11 studies on the prevalence of major depressive disorder (MDD) in the general population and in victims directly affected by terrorist attacks. On average, $4 \%$ to $10 \%$ of the general population displayed MDD within the first few months following a terrorist attack, while the risk of MDD in direct victims ranges between $20 \%$ and $30 \%{ }^{34}$

An extensive body of literature has explored the influence of the $20019 / 11$ terrorist attacks on the mental health of citizens of the United States (US). ${ }^{35}$ Results consistently show that the effect of the terrorist attack was substantial during the first week. For example, Silver et al. show that $90 \%$ of interviewees displayed at least one symptom of stress for at least three to five days following the terrorist event. ${ }^{36}$ Symptoms significantly subsided, however, after two months. Schuster et al. and Schlenger et al. estimate that approximately $7.5 \%$ to $20 \%$ of adults living in New York City displayed symptoms of Post-traumatic Stress Disorder (PTSD) up to two months after the attack; ${ }^{37}$ whereas $5.8 \%$ of the US population living outside the city displayed PTSD symptoms up to six months post attack. ${ }^{38}$

Emotional reactions by Londoners, as a result of the July 2005 terrorist attacks in London, and citizens of Madrid, after the March 2004 terrorist attacks, were similar to the reaction of US citizens. Rubin et al. report that substantial stress symptoms 
were reported by $31 \%$ of those interviewed 11 to 13 days after the London attacks. ${ }^{39}$ Salguero et al. report that $13.3 \%$ of citizens interviewed in Madrid had PTSD symptoms two to three weeks post attack. ${ }^{40}$

Researchers have also studied the long-term effects of the Second Palestinian Intifada in Israel, which started in September 2000 and ended in February 2005. Results from a study by Bleich, Gelkopf, and Solomon show that, of the 512 participants, $84(16.4 \%)$ had been directly exposed to a terrorist attack and 191 (37.3\%) had a family member or friend who had been exposed. ${ }^{41}$ Of the 510 respondents who answered questions related to traumatic stress related (TSR) symptoms, $77 \%$ had at least one symptom, $9.4 \%$ of respondents had PTSD and $58.6 \%$ reported feeling depressed. Bleich et al. conducted a telephone survey using strata sampling of 828 households. In total, 501 people agreed to participate. Employing the same method as in the 2003 study, the authors estimate that after 44 months of Intifada over $86 \%$ of the population had at least one TSR symptom, $9 \%$ had PTSD symptoms and $29.5 \%$ felt depressed. ${ }^{42}$

While PSTD symptoms appear to substantially decrease several months after a terrorist attack, Braithwaite concludes that terrorists are often successful in installing a significant sense of fear into a broader population in the long-term. ${ }^{43}$ Individuals overestimate the likelihood of terrorism attacks and the risk that they will be a victim of future terrorist actions. For example, over $66 \%$ of Londoners remained concerned about another terrorist attack in London over two years after the July 2005 terrorist attacks and $25 \%$ of UK citizens believe that terrorism risk has increased in the five years after the event. Similar patterns are observed among US citizens. For example, Braithwaite reports that over $91 \%$ of US citizens considered terrorism as a vital threat in 2002 , and over $70 \%$ in $2008 .^{44}$ 
A very small body of literature considers the relationship between terrorism and life satisfaction. For example, Frey, Luechinger, and Stutzer use combined crosssection time-series data to estimate the costs of terrorism for France and the British Isles. $^{45}$ The authors find large negative effects of terrorism on life satisfaction. Specifically, an increase of one standard deviation in the number of recorded incidents lowers life satisfaction by 0.012 and 0.013 points on a four point scale for residents of the British Isles and France respectively. An increase of one standard deviation in the number of recorded fatalities is associated with a decrease in life satisfaction of 0.009 points in both countries. These results translate into considerable compensating surpluses for a hypothetical reduction in terrorism. The costs of terrorism are estimated to be approximately $4 \%$ of annual household income in France and $26 \%$ in the British Isles when the most terrorism prone regions are compared to the least terrorism prone regions.

In a similar study, Romanov, Zussman, and Zussman employ data from Israel's Social Survey for the years 2002 to 2004 to investigate the relationship between terrorism and the happiness of Israelis during the second Palestinian Intifada. ${ }^{46}$ They find that terrorism has a limited impact on the life satisfaction of Jewish Israelis, while the life satisfaction of Arab citizens of Israel was negatively affected. The authors suggest that terrorist acts have become a part of everyday life for Jewish Israelis and, as such, does not affect their life satisfaction. On the other hand, the negative effect on the life satisfaction of Arab citizens of Israel may be explained by increasing fear of discrimination.

In terms of inter-country affects, Metcalfe, Powdthavee, and Dolan examine the influence of the $9 / 11$ attacks on the happiness of residents of the United Kingdom. ${ }^{47}$ They found that the attack led to a significant increase in mental distress 
among the United Kingdom population. This impact, however, was short; lasting for only approximately three months.

In a study most closely related to our own, Blomberg et al. employ a large cross-national sample to examine the effect of terrorism on income, including its indirect role through lowering trust. ${ }^{48}$ The authors show that terrorism has a negative and statistically significant impact on individual income. This impact is larger than that previously found in the literature. Blomberg et al. suggest that this is possibly due to aggregation effects and data selection. The authors then estimate the societal impact of terrorism on economic growth by examining the extent to which terrorism reduces trust and how this, in turn, hinders economic performance. A measure of the economic consequences of terrorism is then developed through the estimation of the magnitude of the 'trust tax' from terrorism. This effect, however, is relatively minor compared to the direct impact of terrorism on income.

\section{Empirical strategy}

This paper employs cross-country data on life satisfaction and terrorism, building on recent developments in the economics of happiness literature. Frey and Stutzer provide seminal reviews. ${ }^{49}$ The method employed requires that self-reported life satisfaction be regarded as a good proxy for an individual's utility. Strong support for this position is provided by Lucas and Donnellan and Diener, Inglehart, and Tay. ${ }^{50}$ The theoretical model is similar to that employed by Welsch and consists of two equations: the life satisfaction equation and the income equation. ${ }^{51}$

The life satisfaction equation is specified as:

$w=f\left(y, t, Z_{1}\right)$ 
where $w$ is mean life satisfaction in a country (a measure of social welfare), $y$ is per worker income (real GDP), $t$ is the measure of the level of terrorism, and, $\boldsymbol{Z}_{1}$ is a vector of control variables (e.g. median age and educational attainment) that might confound the link between terrorism and life satisfaction. A priori, worker income is expected to be positively associated with life satisfaction, while terrorism is expected to be negatively associated.

The income equation is a standard production function, as follows:

$y=g\left(k, t, Z_{2}\right)$

where $k$ is the capital stock per worker and $\boldsymbol{Z}_{2}$ is a vector of other relevant controls (e.g. human capital and research). Capital stock per worker is expected to be positively associated with income, while terrorism is expected to be negatively associated.

Substituting Equation (2) into (1) yields the reduced form of the model:

$w=f\left(g\left(k, t, Z_{2}\right), t, Z_{1}\right)$

\section{Estimation strategy}

The life satisfaction and income equations are specified as Cobb-Douglas functions, which explain variation in long-run economic growth rates across countries. ${ }^{52}$ The Cobb-Douglas specification for the life satisfaction equation introduces nonlinearity between the level of terrorism and life satisfaction. ${ }^{53}$

The estimating equation for life satisfaction can be stated as follows:

$w_{i, t}=\alpha_{0}+\alpha_{1} y_{i, t}+\alpha_{2} t_{i, t-1}+\sum_{j=3}^{k} \alpha_{j} Z_{1, i, t}+\tau_{t}+\varepsilon_{1 i, t}$ 
where $w_{i, t}$ is the natural $\log$ of mean life satisfaction of country $i$ at time $t ; y_{i, t}$ is the natural $\log$ of real GDP per worker; $t_{i, t-1}$ is the lag of the natural log of the terrorism measure ${ }^{54} ; \boldsymbol{Z}_{1 i, t}$ represents control variables including, for example, the natural log of median age and the natural $\log$ of mean educational attainment (with coefficients $\alpha_{j}$ where $j=3 \ldots \mathrm{k}$, where $\mathrm{k}$ is the sum of the independent and control variables); $\tau_{t}$ denotes year fixed effects; and $\varepsilon_{1, i, t}$ is the error term. Employing the lag of the terrorism measure makes a causal interpretation plausible. Further, to address the potential problem of reverse casuality (i.e. the case were low (high) life satisfaction leads to high (low) levels of terrorist activity) we include a measure of polity as a proxy for societal conflicts and grievances as a control variable in both Equations 4 and 5. The polity measure examines qualities of governing authorities, ranking countries from -10 (hereditary monarchy) to +10 (consolidated democracy). Of most relevance, one of the six components of the polity measure is "extent to which alternative preferences for policy and leadership can be pursued in the political arena". A more direct measure of societal conflict cannot be employed as these measures are highly correlated with the terrorism variable, which includes both domestic and international events.

The estimating equation for income can be stated as follows:

$y_{i, t}=\beta_{0}+\beta_{1} k_{i, t}+\beta_{2} t_{i, t-1}+\sum_{j=3}^{k} \beta_{j} Z_{2, i, t}+\tau_{t}+\varepsilon_{2 i, t}$

where $k_{i, t}$ denotes the natural $\log$ of physical capital stock per worker; $\boldsymbol{Z}_{2, i, t}$ represents control variables including, for instance, the natural log of mean total years of schooling; $\tau_{t}$ is year fixed effects; and $\varepsilon_{2, i, t}$ denotes the error term. 
Equations (4) and (5) are estimated as a system. It should be noted that the system is not independent; income is assumed to affect life satisfaction, although not the reverse. For a recursive system of equations such as this, where the errors are conjectured to be correlated across equations, it is useful to estimate the system using Seemingly Unrelated Regressions (SUR). SUR estimation is equivalent to maximum likelihood estimation in the present circumstances, providing gains in terms of efficiency whilst also accounting for heteroskedasticity and correlation of errors across equations. ${ }^{55}$

Many researchers in the economics of happiness literature appeal to the findings of Ferrer-i-Carbonell and Frijters to justify the estimation technique employed. ${ }^{56}$ In particular these authors find that treating the life satisfaction variable as a continuous variable with cardinal qualities yields qualitatively similar results to those estimation techniques that treat the dependent variable as strictly ordinal. Kahneman is often cited as considering this distinction more of a theoretical, rather than a practical, difficulty. ${ }^{57}$ Nonetheless, treating the dependent variable as continuous may result in estimates that predict values outside of the ordered range. As a result, a single equation tobit model is compared to a single equation ordinary least squares (OLS) model to check the robustness of results. As reported in Appendix A, this does not significantly change the results.

\section{Data and variables}

The dataset contains data for 117 countries covering the period 2006 to 2011, yielding a total of 626 observations. The panel is unbalanced as mean life satisfaction is missing for some counties over this period. 
The life satisfaction variable comes from the World Happiness Database. ${ }^{58}$ The database provides average self-reported levels of life satisfaction by country and year, elicited from individuals' responses to the question:

Here is a ladder representing the 'ladder of life'. Let's suppose the top of the ladder represents the best possible life for you; and the bottom, the worst possible life for you. On which step of the ladder do you feel you personally stand at the present time?

The responses are rated on a scale of 0 (worst possible life satisfaction) to 10 (best possible life satisfaction). Country level mean life satisfaction is linearly interpolated over time for countries missing data on life satisfaction for particular years.

Data on the level of terrorism is obtained from the Global Terrorism Database (GTD). The GTD defines terrorism as "the threatened or actual use of illegal force and violence by a non-state actor to attain a political, economic, religious, or social goal through fear, coercion, or intimidation." Both domestic and international terrorist event are included. In addition, at least two of the following three criteria has to be met to be included in the GTD: (1) the act must be aimed at attaining a political, economic, religious, or social goal; (2) there must be evidence of an intention to coerce, intimidate, or convey some other message to a larger audience (or audiences) than the immediate victims; and (3) the action must be outside the context of legitimate warfare activities. ${ }^{59}$

From the GTD a Global Terrorism Index (GTI) can be calculated as follows: 
Terrorism Index $=$

$1 \mathrm{x}$ incidents $+3 \mathrm{x}$ fatalities $+0.5 \mathrm{x}$ injuries $+2 \mathrm{x}$ property damage

Where incidents is the total number of terrorist incidents in a given year, fatalities is the total number of fatalities caused by terrorists in a given year, injuries is the total number of injuries caused by terrorists in a given year and property damage is the approximate level of total property damage from terrorist incidents in a given year. The GTI is an index designed to systematically rank and compare countries according to the impact of terrorism. The weightings of each component are intended to reflect the latent psychological effect of terrorist acts over time. ${ }^{60}$

Initially Equations 4 and 5 are estimated for the full sample of countries separately for each of the four components of the GTI and for the GTI itself. Noting that 27 of the countries in the sample did not experience any form of terrorist attack between 2006 and 2011. The sample is then truncated to exclude these countries in an attempt to more clearly identify the effect of a terrorist attack on social welfare in countries that have actually been exposed to a terrorist event. The results for two samples are then compared. The list of countries included in each sample is provided as Appendix B. The list of all variables employed, their respective data sources and summary statistics are provided in Table 1. Pairwise correlations are presented as Appendix C.

'Table 1 here'

\section{Results}

Considering first the estimation of Equation 4 for the full sample (Table 2 Part A), irrespective of the measure of terrorism employed, it is clear that real GDP per worker and polity (a measure of democracy) are strongly positively associated with life 
satisfaction. No statistically significant relationship is found between life satisfaction and age or human capital. Terrorism measures are of the expected (negative) sign. The only significant terrorism measure, however, is fatalities ( $p$-value 0.059). It should be noted that both injuries and the GTI are close to being significant at the $10 \%$ level (p-values of 0.106 and 0.194 respectively).

In regards to the estimation of Equation 5 for the full sample (Table 2 Part B), human capital and capital stock per worker are strongly positively associated with real GDP per worker across all models. No relationship is found between polity and real GDP per worker. Counter to a priori expectations, all of the terrorism measures indicate a positive relationship between terrorism and real GDP per worker, although none are significant.

'Table 2 here'

Results for the estimation of Equation 4 with the truncated sample are presented in Table 3 Part A. The explanatory power of this model is substantially higher than the full sample model (adjusted- $\mathrm{R}^{2}$ of approximately 0.64 compared with 0.56). Results between the two models are also substantially different. For example, age is now negatively associated with life satisfaction across all terrorism measures (statistically significant at the 5\% level). Similarly, and contrary to a priori expectations, human capital is also negatively associated with life satisfaction (statistically significant at the 5\% level). Consistent with the full sample model, both real GDP per worker and polity are strongly positively associated with life satisfaction. With respect to terrorism, results differ to the full sample model in that fatalities, injuries and the GTI are all negatively associated with life satisfaction, statistically significant at the $10 \%$ level. Further, terrorism incidents and property damage are negative and close to being significant at the $10 \%$ level (both with p- 
values of 0.101). This supports the hypothesis that terrorism is more significantly associated with life satisfaction in countries exposed to terrorist events.

Results from the estimation of Equation 5 with the truncated sample are presented in Table 3 Part B. Results demonstrate that both human capital and capital stock per worker, similar to the full sample results, are positively associated with real GDP per worker at the $1 \%$ level. All terrorism measures, however, have changed sign - now showing a negative association (although not significant at conventional levels). It should be noted that injuries and fatalities are close to being significant (both with p-values of 0.115 ).

'Table 3 here'

\section{Robustness checks}

To check the robustness of the findings, a number of tests are undertaken. First, we re-estimate the results without the inclusion of the polity control variable. While the pairwise correlation coefficients between polity and our measures of terrorism are low (Appendix C), previous research finds a significant association between democracy and terrorism. ${ }^{61}$ The low pairwise correlation coefficients could, therefore, be a result of a non-linear relationship between democracy and terrorism. ${ }^{62}$ As shown in Tables 4 and 5, excluding polity strengthens the significance of the terrorist variables in the life satisfaction equation for both the full and truncated samples.

'Table 4 here'

'Table 5 here'

The pairwise correlation between age and human capital is large (0.76). To check for possible multicollinearity, we re-estimate the model without the inclusion of 
the age control variable. Tables 6 and 7 provide evidence that the results of our analysis are stable and do not substantively change with the exclusion of the age variable.

'Table 6 here'

'Table 7 here'

Because mean life satisfaction in individual countries typically changes very slowly over time, autocorrelation may be present. We attempt to account for autocorrelation in the error terms by including the first order lag in the life satisfaction equation. The inclusion of this lag does not affect the sign or significance of the terrorism variables.

We then split the truncated sample by OECD and non-OECD members. In regards to the estimation of Equation 4 for OECD members (Table 8 Part A), the terrorism measures are all negative and significant at the $1 \%$ level. In regards to the estimation of Equation 5, (Table 8 Part B), the terrorism measures are all positive but not significant, with the exception of fatalities which is positively and significantly associated with GDP per worker at the $1 \%$ level. For non-OECD members, the estimation of Equation 4 (Table 9 Part A) shows that all terrorism measures are negatively associated with life satisfaction, but at statistically insignificant levels. Conversely, the estimation of Equation 5 (Table 9 Part B) reveals that incidents, injuries and the GTI have a negative and statistically significant association (at the 5\% level) with real GDP per worker (Table 9 Part B).

'Table 8 here'

'Table 9 here' 


\section{Discussion}

This paper sets out to analyse the link between life satisfaction and terrorism, in particular, both the direct effect of terrorism on life satisfaction as well as the indirect effect of terrorism on life satisfaction via its effect on national income. Arguably, the most notable finding is the generally significant and negative association found between terrorism and life satisfaction, while no such association is found between terrorism and real GDP per worker. This implies that the true social costs of terrorism may not be adequately reflected in conventional economic data and, therefore, studies seeking to evaluate the cost of terrorism should consider employing datasets that capture subjective elements of welfare. This is not to say that conventional economic data is of no use; rather subjective data can be used to augment conventional analyses of economic data to yield a more nuanced understanding of the issue. This view is consistent with the growing recognition that subjective measures (such as those provided by self-reports of life satisfaction or happiness) have an important role to play in policy development and evaluation. For example, the Commission on the Measurement of Economic Performance and Social Progress reports that both objective and subjective indicators of progress are important, placing them on an equal footing. The Commission states:

Research has shown that it is possible to collect meaningful and reliable data on subjective as well as objective wellbeing. Subjective wellbeing encompasses different aspects (cognitive evaluations of one's life, happiness, satisfaction, positive emotions, such as joy and pride, and negative emotions such as pain and worry): each of them should be measured separately to derive a more comprehensive appreciation of people's lives.... ${ }^{63}$ 
With respect to the lack of any significant relationship between terrorism and real GDP per worker, this result is consistent with a number of other studies that observe very modest and short-term economic consequences of terrorism. ${ }^{64}$ For example, Chen and Siems find that the effect of major terrorist attacks on capital markets, on average, lasts from one to three days. ${ }^{65}$ Further, our results are consistent with Tavares, who shows that terrorism has no significant relationship with economic growth after controlling for conventional economic growth indicators (e.g. human capital, capital stocks etc.). ${ }^{66} \mathrm{~A}$ finding which suggests that nations wishing to remain resilient to the economic impacts of terrorism may benefit from bolstering such economic growth indicators; in particular, those characteristics associated with OECD countries, such as the maintenance and integrity of political rights.

Truncating the sample to those countries that have experienced a terrorist incident in the years under consideration marginally increases the strength of the negative association between life satisfaction and our measures of terrorism. This suggests that direct experience of terrorism heightens the sensitivity of the population to the consequences of terrorism. In other words, the effect of terrorism on life satisfaction is greater in those countries that have experienced a terrorism event than in those that have not. In regards to our alternative measures of terrorism, we find people are more sensitive to fatalities and injuries than to property damage or the number of terrorist incidents. This suggests that the human cost of terrorism is more damaging than the material cost. These results are robust to the exclusion of the polity and age control variables.

For OECD members, terrorism has a pronounced effect on life satisfaction, with a negative and statistically significant association found across all measures of terrorism at the $1 \%$ level. While in contrast, a positive association is found between 
terrorism and GDP per worker, although this is only significant for the fatalities terrorism measure. This suggests that, to some extent, terrorism promotes economic activity among OECD countries, perhaps through increased security and intelligence spending. For non-OECD members, however, the reverse appears to be the case. That is, no significant association is found between terrorism and life satisfaction, whereas a negative association is found between three of the terrorism measures (incidents, injuries and GTI) and GDP per worker. These associations between terrorism and GDP per worker are broadly consistent with the findings of Blomberg, Hess and Orphanides, who show a small and statistically insignificant negative association between terrorism and economic growth within OECD members, and a negative and significant association for non-OECD members. ${ }^{67}$

The stark difference between the strongly negative life satisfaction effects for OECD countries versus the insignificant effects for non-OECD countries is intriguing. The polarised results point to the comparative fragility of life satisfaction in OECD countries which have experienced far fewer terrorist events than countries outside of the OECD (only five percent of terrorist fatalities since 2000 have occurred in OECD countries). ${ }^{68}$ In comparison, non-OECD countries appear to exhibit a relative psychological resilience to terrorism. In countries with frequent terrorist activity, violence could have become part of everyday life. For example, studies have found that despite continuous terrorist threats in Israel, symptions of depression among the Israeli population decreased from $58.6 \%$ in 2002 to $29.5 \%$ in $2004^{69}$. In addition, citizens of countries with frequent terrorist attacks may also more accurately estimate the probability of being a victim. Becker and Rubenstein show that frequent users of public transport in Israel did not decrease their use of buses after terrorist attacks on public transport. In contrast, occasional users of public transport reduced their 
frequency of use ${ }^{70}$. Similarly, during the three month period after the $9 / 11$ terrorist attacks, the number of US citizens who died in car crashes having avoided air travel was higher than the number of people killed in the four fatal $9 / 11$ flights $^{71}$. Alternatively, media coverage of terrorist events is likely to trigger fear and anxiety. It is, therefore, possible that terrorist events in OECD countries have a larger impact on the population due to higher levels of press freedom ${ }^{72}$. It is also plausible that the most distressed citizens of non-OECD countries have migrated to OECD countries where the threat of terrorism is markedly lower. Finally, an alternative explanation is that this finding is an artefact of the data (i.e. that citizens of OECD and non-OECD member countries answer life satisfaction questions differently). The issue of cultural measurement bias or the effect of culture on life satisfaction responses, however, is explicitly explored by Veenhoven, who concludes that “...differences [in average life satisfaction scores] cannot be denounced as mere measurement bias, nor can they be explained as a result of cultural differences in the evaluation of life.,"73

In all, the results of this study suggest that the social costs of terrorism are potentially much higher than the economic costs, particularly for OECD member countries. This suggests that measuring only the conventional economic costs of terrorism significantly underestimates the true costs of terrorism. This has implications for the evaluation of policy responses to terrorism, in particularly when weighing up the benefits and costs of public expenditure. Ceteris paribus, ignoring the social costs may lead to lower levels of expenditure than that which is truly optimal. 


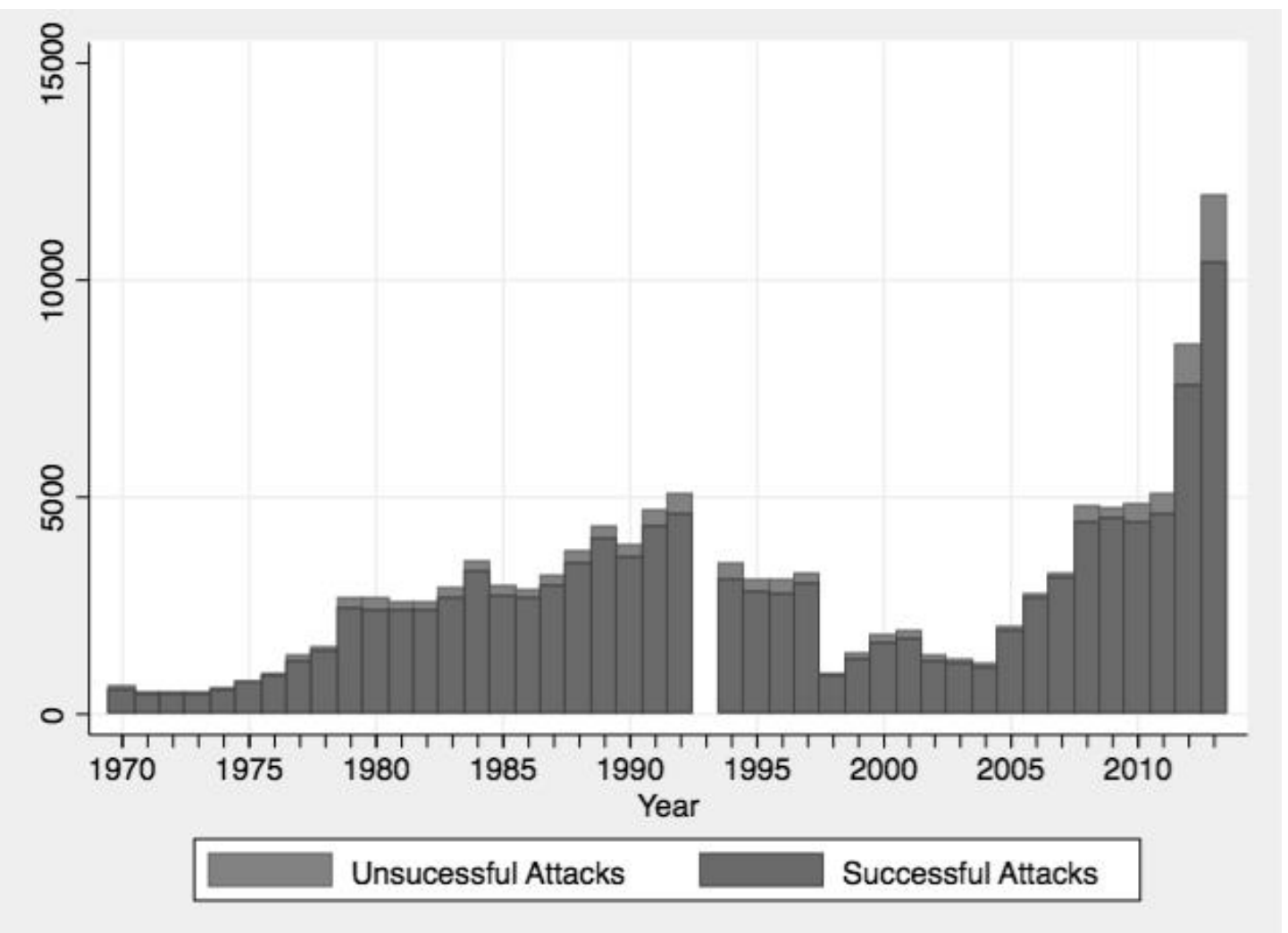

Figure 1. Number of terrorist attacks since 1970

Source: Global Terrorism Database ${ }^{74}$ 
Table 1. Data summary statistics

\begin{tabular}{|c|c|c|c|c|c|}
\hline Variable name & Definition & Source & Observations & Mean (SD) & [Minimum, Maximum] \\
\hline Life satisfaction & $\begin{array}{l}\text { Mean self-reported life satisfaction (scale } \\
0 \text {-10) (linearly interpolated between } \\
\text { available observations) }\end{array}$ & Veenhoven $^{75}$ & 629 & $\begin{array}{r}5.60 \\
(1.09)\end{array}$ & {$[2.9,8]$} \\
\hline Fatalities (lag) & $\begin{array}{l}\text { Total number of fatalities caused by } \\
\text { terrorists in a given year }\end{array}$ & $\begin{array}{l}\text { Institute for Economics } \\
\text { and Peace }\end{array}$ & 629 & $\begin{array}{c}59.68 \\
(381.33)\end{array}$ & {$[0,6,100]$} \\
\hline Property damage (lag) & $\begin{array}{l}\text { A measure of the total property damage } \\
\text { from terrorist incidents in a given year }\end{array}$ & $\begin{array}{l}\text { Institute for Economics } \\
\text { and Peace }\end{array}$ & 629 & $\begin{array}{r}8.13 \\
(42.31)\end{array}$ & {$[0,673]$} \\
\hline GTI (lag) & $\begin{array}{l}\text { A weighted average of four terrorist } \\
\text { measures, calculated by } 1 \mathrm{x} \text { incidents }+3 \\
\mathrm{x} \text { fatalities }+0.5 \mathrm{x} \text { injuries }+2 \mathrm{x} \text { property } \\
\text { damage }\end{array}$ & $\begin{array}{l}\text { Institute for Economics } \\
\text { and Peace }\end{array}$ & 629 & $\begin{array}{c}286.38 \\
(1713.00)\end{array}$ & {$[0,25,666]$} \\
\hline $\begin{array}{l}\text { Capital stock per } \\
\text { worker }\end{array}$ & $\begin{array}{l}\text { Capital stock per capita at constant } 2005 \\
\text { national prices (in } 2005 \text { USD) per worker }\end{array}$ & $\begin{array}{l}\text { Feenstra, Inklaar, \& } \\
\text { Timmer }^{82}\end{array}$ & 629 & $\begin{array}{c}93,354.15 \\
(87,229.89)\end{array}$ & {$[1,246.86,404,698.20]$} \\
\hline Human capital & $\begin{array}{l}\text { Mean total years of schooling (linearly } \\
\text { interpolated between available } \\
\text { observations) }\end{array}$ & $\begin{array}{l}\text { Feenstra, Inklaar, \& } \\
\text { Timmer }^{83}\end{array}$ & 629 & $\begin{array}{c}8.23 \\
(2.71)\end{array}$ & {$[1.35,13.09]$} \\
\hline Polity & $\begin{array}{l}\text { Rescaled from } 1 \text { (full autocracy) to } 10 \\
\text { (full democracy) }\end{array}$ & Marshall $^{84}$ & 621 & $\begin{array}{c}7.99 \\
(2.49)\end{array}$ & {$[1,10]$} \\
\hline Age & Median age of a country's citizens & $\begin{array}{l}\text { UNESCO Institute for } \\
\text { Statistics }^{85}\end{array}$ & 629 & $\begin{array}{l}29.09 \\
(8.70)\end{array}$ & {$[14.90,44.90]$} \\
\hline
\end{tabular}


Table 2. Model results - full sample

\begin{tabular}{|c|c|c|c|c|c|}
\hline & Incidents & Fatalities & Injuries & $\begin{array}{l}\text { Property } \\
\text { Damage }\end{array}$ & GTI \\
\hline Part A & $\begin{array}{c}\ln (\text { Life } \\
\text { satisfaction })\end{array}$ & $\begin{array}{c}\ln (\text { Life } \\
\text { satisfaction })\end{array}$ & $\begin{array}{c}\ln (\text { Life } \\
\text { satisfaction) }\end{array}$ & $\begin{array}{c}\ln (\text { Life } \\
\text { satisfaction) }\end{array}$ & $\begin{array}{c}\ln (\text { Life } \\
\text { satisfaction) }\end{array}$ \\
\hline $\ln ($ Age $)$ & $\begin{array}{l}-0.0330 \\
(0.0342)\end{array}$ & $\begin{array}{l}-0.0362 \\
(0.0342)\end{array}$ & $\begin{array}{l}-0.0333 \\
(0.0341)\end{array}$ & $\begin{array}{l}-0.0330 \\
(0.0342)\end{array}$ & $\begin{array}{l}-0.0340 \\
(0.0342)\end{array}$ \\
\hline $\ln$ (RGDP per worker) & $\begin{array}{c}0.1336 * * * \\
(0.0085)\end{array}$ & $\begin{array}{c}0.1334 * * * \\
(0.0084)\end{array}$ & $\begin{array}{c}0.1333 * * * \\
(0.0084)\end{array}$ & $\begin{array}{c}0.1336 * * * \\
(0.0085)\end{array}$ & $\begin{array}{c}0.1337 * * * \\
(0.0085)\end{array}$ \\
\hline $\ln$ (Human capital) & $\begin{array}{l}-0.0114 \\
(0.0216)\end{array}$ & $\begin{array}{l}-0.0135 \\
(0.0216)\end{array}$ & $\begin{array}{l}-0.0117 \\
(0.0215)\end{array}$ & $\begin{array}{l}-0.0107 \\
(0.0216)\end{array}$ & $\begin{array}{l}-0.0123 \\
(0.0220)\end{array}$ \\
\hline $\ln$ (Polity) & $\begin{array}{c}0.0532 * * * \\
(0.0125)\end{array}$ & $\begin{array}{c}0.0517 * * * \\
(0.0125)\end{array}$ & $\begin{array}{c}0.0521 * * * \\
(0.0125)\end{array}$ & $\begin{array}{c}0.0533 * * * \\
(0.0125)\end{array}$ & $\begin{array}{c}0.0525 * * * \\
(0.0150)\end{array}$ \\
\hline $\ln ($ Terrorism) (lag) & $\begin{array}{l}-0.0039 \\
(0.0035)\end{array}$ & $\begin{array}{c}-0.0061 * \\
(0.0032)\end{array}$ & $\begin{array}{l}-0.0044 \\
(0.0027)\end{array}$ & $\begin{array}{l}-0.0048 \\
(0.0047)\end{array}$ & $\begin{array}{l}-0.0031 \\
(0.0024)\end{array}$ \\
\hline Constant & $\begin{array}{c}0.4269 * * * \\
(0.0651)\end{array}$ & $\begin{array}{c}0.4492 * * * \\
(0.0661)\end{array}$ & $\begin{array}{c}0.4352 * * * \\
(0.0653)\end{array}$ & $\begin{array}{c}0.4242 * * * \\
(0.0651)\end{array}$ & $\begin{array}{c}0.4337 * * * \\
(0.0653)\end{array}$ \\
\hline Adjusted-R ${ }^{2}$ & 0.5642 & 0.5660 & 0.5653 & 0.5641 & 0.5646 \\
\hline Part B & $\begin{array}{l}\ln (\text { RGDP per } \\
\text { worker })\end{array}$ & $\begin{array}{l}\ln (\text { RGDP per } \\
\text { worker })\end{array}$ & $\begin{array}{l}\ln (\text { RGDP per } \\
\quad \text { worker })\end{array}$ & $\begin{array}{l}\ln (\text { RGDP per } \\
\text { worker })\end{array}$ & $\begin{array}{c}\ln (\text { RGDP per } \\
\text { worker })\end{array}$ \\
\hline ln(Human capital) & $\begin{array}{c}0.3737 * * * \\
(0.0586)\end{array}$ & $\begin{array}{c}0.3721 * * * \\
(0.0588)\end{array}$ & $\begin{array}{c}0.3700 * * * \\
(0.0585)\end{array}$ & $\begin{array}{c}0.3730 * * * \\
(0.0585)\end{array}$ & $\begin{array}{c}0.3761 * * * \\
(0.0588)\end{array}$ \\
\hline $\ln$ (Capital stock per worker) & $\begin{array}{c}0.7789 * * * \\
(0.0181)\end{array}$ & $\begin{array}{c}0.7797 * * * \\
(0.0180)\end{array}$ & $\begin{array}{c}0.7796 * * * \\
(0.0180)\end{array}$ & $\begin{array}{c}0.7787 * * * \\
(0.0181)\end{array}$ & $\begin{array}{c}0.7789 * * * \\
(0.0180)\end{array}$ \\
\hline $\ln$ (Polity) & $\begin{array}{l}-0.0056 \\
(0.0353)\end{array}$ & $\begin{array}{l}-0.0039 \\
(0.0353)\end{array}$ & $\begin{array}{l}-0.0044 \\
(0.0353)\end{array}$ & $\begin{array}{l}-0.0060 \\
(0.0353)\end{array}$ & $\begin{array}{l}-0.0044 \\
(0.0352)\end{array}$ \\
\hline $\ln$ (Terrorism) (lag) & $\begin{array}{c}0.0057 \\
(0.0104)\end{array}$ & $\begin{array}{c}0.0028 \\
(0.0095)\end{array}$ & $\begin{array}{c}0.0006 \\
(0.0081)\end{array}$ & $\begin{array}{c}0.0081 \\
(0.0137)\end{array}$ & $\begin{array}{c}0.0053 \\
(0.0070)\end{array}$ \\
\hline Constant & $\begin{array}{c}0.6002 * * * \\
(0.1461)\end{array}$ & $\begin{array}{c}0.5936 * * * \\
(0.1495)\end{array}$ & $\begin{array}{c}0.6017 * * * \\
(0.1472)\end{array}$ & $\begin{array}{c}0.6043 * * * \\
(0.1461)\end{array}$ & $\begin{array}{c}0.5893 * * * \\
(0.1471)\end{array}$ \\
\hline Adjusted- $\mathrm{R}^{2}$ & 0.8980 & 0.8980 & 0.8980 & 0.8980 & 0.8981 \\
\hline Observations & 621 & & & & \\
\hline
\end{tabular}

*** significant at the $1 \%$ level; ** significant at the $5 \%$ level; * significant at the $10 \%$ level. Year fixed effects also included as controls. Standard errors in parentheses. 
Table 3. Model results - truncated sample

\begin{tabular}{|c|c|c|c|c|c|}
\hline & Incidents & Fatalities & Injuries & $\begin{array}{l}\text { Property } \\
\text { Damage }\end{array}$ & GTI \\
\hline Part A & $\begin{array}{c}\ln (\text { Life } \\
\text { satisfaction })\end{array}$ & $\begin{array}{c}\ln (\text { Life } \\
\text { satisfaction })\end{array}$ & $\begin{array}{c}\ln (\text { Life } \\
\text { satisfaction) }\end{array}$ & $\begin{array}{c}\ln (\text { Life } \\
\text { satisfaction })\end{array}$ & $\begin{array}{c}\ln (\text { Life } \\
\text { satisfaction) }\end{array}$ \\
\hline $\ln ($ Age $)$ & $\begin{array}{c}-0.1069 * * \\
(0.0360)\end{array}$ & $\begin{array}{c}-0.1117 * * \\
(0.0360)\end{array}$ & $\begin{array}{c}-0.1073 * * \\
(0.0359)\end{array}$ & $\begin{array}{c}-0.1066^{* *} \\
(0.0360)\end{array}$ & $\begin{array}{c}-0.1084 * * \\
(0.0359)\end{array}$ \\
\hline $\ln$ (RGDP per worker) & $\begin{array}{c}0.1736 * * * \\
(0.0092)\end{array}$ & $\begin{array}{c}0.1728 * * * \\
(0.0092)\end{array}$ & $\begin{array}{c}0.1728 * * * \\
(0.0092)\end{array}$ & $\begin{array}{c}0.1739 * * * \\
(0.0092)\end{array}$ & $\begin{array}{c}0.1734 * * * \\
(0.0092)\end{array}$ \\
\hline $\ln$ (Human capital) & $\begin{array}{c}-0.0577 * * \\
(0.0217)\end{array}$ & $\begin{array}{c}-0.0575 * * \\
(.0217)\end{array}$ & $\begin{array}{c}-0.0564 * * \\
(0.0216)\end{array}$ & $\begin{array}{c}-0.0573 * * \\
(0.0217)\end{array}$ & $\begin{array}{c}-0.0578 * * \\
(0.0217)\end{array}$ \\
\hline $\ln$ (Polity) & $\begin{array}{c}0.0817 * * * \\
(0.0128)\end{array}$ & $\begin{array}{c}0.0796 * * * \\
(0.0128)\end{array}$ & $\begin{array}{c}0.0798 * * * \\
(0.0128)\end{array}$ & $\begin{array}{c}0.0818 * * * \\
(0.0128)\end{array}$ & $\begin{array}{c}0.0805 * * * \\
(0.01285)\end{array}$ \\
\hline $\ln$ (Terrorism) (lag) & $\begin{array}{l}-0.0056 \\
(0.0034)\end{array}$ & $\begin{array}{c}-0.0060 * \\
(0.0031)\end{array}$ & $\begin{array}{c}-0.0046^{*} \\
(0.0026)\end{array}$ & $\begin{array}{l}-0.0072 \\
(0.0044)\end{array}$ & $\begin{array}{l}-0.0039 * \\
(0.0023)\end{array}$ \\
\hline Constant & $\begin{array}{c}0.3198 * * * \\
(0.0693)\end{array}$ & $\begin{array}{c}0.3477 * * * \\
(0.0713)\end{array}$ & $\begin{array}{c}0.3301 * * * \\
(0.0697)\end{array}$ & $\begin{array}{c}0.3133 * * * \\
(0.0692)\end{array}$ & $\begin{array}{c}0.3315 * * * \\
(0.0700)\end{array}$ \\
\hline Adjusted-R ${ }^{2}$ & 0.6414 & 0.6424 & 0.6419 & 0.6412 & 0.6416 \\
\hline Part B & $\begin{array}{l}\ln (\text { RGDP per } \\
\text { worker })\end{array}$ & $\begin{array}{l}\ln (\text { RGDP per } \\
\text { worker })\end{array}$ & $\begin{array}{l}\ln (\text { RGDP per } \\
\text { worker })\end{array}$ & $\begin{array}{l}\ln (\text { RGDP per } \\
\text { worker })\end{array}$ & $\begin{array}{l}\ln (\text { RGDP per } \\
\text { worker })\end{array}$ \\
\hline $\ln$ (Human capital) & $\begin{array}{c}0.4826 * * * \\
(0.0607)\end{array}$ & $\begin{array}{c}0.4778 * * * \\
(0.0607)\end{array}$ & $\begin{array}{c}0.4826 * * * \\
(0.0604)\end{array}$ & $\begin{array}{c}0.4870 * * * \\
(0.0606)\end{array}$ & $\begin{array}{c}0.4807 * * * \\
(0.0607)\end{array}$ \\
\hline $\ln$ (Capital stock per worker) & $\begin{array}{c}0.7112 * * * \\
(0.0196)\end{array}$ & $\begin{array}{c}0.7084 * * * \\
(0.0197)\end{array}$ & $\begin{array}{c}0.7097 * * * \\
(0.0196)\end{array}$ & $\begin{array}{c}0.7111 * * * \\
(0.0197)\end{array}$ & $\begin{array}{c}0.7104 * * * \\
(0.0196)\end{array}$ \\
\hline $\ln$ (Polity) & $\begin{array}{l}-0.0079 \\
(0.0374)\end{array}$ & $\begin{array}{l}-0.0140 \\
(0.0371)\end{array}$ & $\begin{array}{l}-0.0119 \\
(0.0372)\end{array}$ & $\begin{array}{l}-0.0098 \\
(0.0375)\end{array}$ & $\begin{array}{l}-0.0107 \\
(0.0372)\end{array}$ \\
\hline $\ln$ (Terrorism) (lag) & $\begin{array}{l}-0.0117 \\
(0.0108)\end{array}$ & $\begin{array}{l}-0.0152 \\
(0.0097)\end{array}$ & $\begin{array}{l}-0.0129 \\
(0.0082)\end{array}$ & $\begin{array}{l}-0.0070 \\
(0.0139)\end{array}$ & $\begin{array}{l}-0.0090 \\
(0.0072)\end{array}$ \\
\hline Constant & $\begin{array}{c}1.1660 * * * \\
(0.1607)\end{array}$ & $\begin{array}{c}1.2235 * * * \\
(0.1661)\end{array}$ & $\begin{array}{c}1.1953 * * * \\
(0.1622)\end{array}$ & $\begin{array}{c}1.1539 * * * \\
(0.1604)\end{array}$ & $\begin{array}{c}1.1893 * * * \\
(0.1628)\end{array}$ \\
\hline Adjusted-R ${ }^{2}$ & 0.8962 & 0.8964 & 0.8964 & 0.8960 & 0.8962 \\
\hline Observations & 500 & & & & \\
\hline
\end{tabular}


Table 4. Abridged model results - full sample, excluding polity

\begin{tabular}{|c|c|c|c|c|c|}
\hline & Incidents & Fatalities & Injuries & $\begin{array}{l}\text { Property } \\
\text { Damage }\end{array}$ & GTI \\
\hline Part A & $\begin{array}{c}\ln (\text { Life } \\
\text { satisfaction })\end{array}$ & $\begin{array}{c}\ln (\text { Life } \\
\text { satisfaction })\end{array}$ & $\begin{array}{c}\ln (\text { Life } \\
\text { satisfaction })\end{array}$ & $\begin{array}{c}\ln (\text { Life } \\
\text { satisfaction) }\end{array}$ & $\begin{array}{c}\ln (\text { Life } \\
\text { satisfaction) }\end{array}$ \\
\hline $\ln ($ Terrorism) (lag) & $\begin{array}{c}-0.0062 * \\
(0.0035)\end{array}$ & $\begin{array}{c}-0.0091 * * * \\
(0.0031)\end{array}$ & $\begin{array}{c}-0.0068 * * * \\
(0.0027)\end{array}$ & $\begin{array}{l}-0.0079 * \\
(0.0045)\end{array}$ & $\begin{array}{c}-0.0048 * * \\
(0.0023)\end{array}$ \\
\hline Adjusted-R ${ }^{2}$ & 0.5514 & 0.5552 & 0.5538 & 0.5513 & 0.5521 \\
\hline Part B & $\begin{array}{l}\ln (\text { RGDP per } \\
\text { worker) }\end{array}$ & $\begin{array}{l}\ln (\text { RGDP per } \\
\text { worker })\end{array}$ & $\begin{array}{l}\ln (\text { RGDP per } \\
\text { worker })\end{array}$ & $\begin{array}{l}\ln (\text { RGDP per } \\
\text { worker })\end{array}$ & $\begin{array}{c}\ln (\text { RGDP per } \\
\text { worker })\end{array}$ \\
\hline $\ln$ (Terrorism) (lag) & $\begin{array}{c}0.0111 \\
(0.0099)\end{array}$ & $\begin{array}{c}0.0085 \\
(0.0090)\end{array}$ & $\begin{array}{c}0.0055 \\
(0.0077)\end{array}$ & $\begin{array}{c}0.0154 \\
(0.0130)\end{array}$ & $\begin{array}{c}0.0087 \\
(0.0066)\end{array}$ \\
\hline Adjusted-R ${ }^{2}$ & 0.8982 & 0.8981 & 0.8980 & 0.8982 & 0.8982 \\
\hline Observations & 629 & & & & \\
\hline
\end{tabular}


Table 5. Abridged model results - truncated sample, excluding polity

\begin{tabular}{|c|c|c|c|c|c|}
\hline & Incidents & Fatalities & Injuries & $\begin{array}{l}\text { Property } \\
\text { Damage }\end{array}$ & GTI \\
\hline Part A & $\begin{array}{c}\ln (\text { Life } \\
\text { satisfaction) }\end{array}$ & $\begin{array}{c}\ln (\text { Life } \\
\text { satisfaction) }\end{array}$ & $\begin{array}{c}\ln (\text { Life } \\
\text { satisfaction) }\end{array}$ & $\begin{array}{c}\ln (\text { Life } \\
\text { satisfaction })\end{array}$ & $\begin{array}{c}\ln (\text { Life } \\
\text { satisfaction) }\end{array}$ \\
\hline $\ln ($ Terrorism) (lag) & $\begin{array}{c}-0.0075 * * \\
(0.0034)\end{array}$ & $\begin{array}{c}-0.0095 * * * \\
(0.0030)\end{array}$ & $\begin{array}{c}-0.0074 * * * \\
(0.0026)\end{array}$ & $\begin{array}{c}-0.0097 * * \\
(0.0348)\end{array}$ & $\begin{array}{c}-0.0057 * * \\
(0.0023)\end{array}$ \\
\hline Adjusted-R ${ }^{2}$ & 0.6113 & 0.6152 & 0.6139 & 0.6112 & 0.6123 \\
\hline Part B & $\begin{array}{l}\ln (\text { RGDP per } \\
\text { worker })\end{array}$ & $\begin{array}{c}\ln (\text { RGDP per } \\
\text { worker })\end{array}$ & $\begin{array}{l}\ln (\text { RGDP per } \\
\text { worker })\end{array}$ & $\begin{array}{l}\ln (\text { RGDP per } \\
\text { worker })\end{array}$ & $\begin{array}{c}\ln (\text { RGDP per } \\
\text { worker })\end{array}$ \\
\hline $\ln ($ Terrorism) (lag) & $\begin{array}{l}-0.0054 \\
(0.0102)\end{array}$ & $\begin{array}{l}-0.0079 \\
(0.0091)\end{array}$ & $\begin{array}{l}-0.0072 \\
(0.0078)\end{array}$ & $\begin{array}{c}0.0006 \\
(0.0131)\end{array}$ & $\begin{array}{l}-0.0048 \\
(0.0069)\end{array}$ \\
\hline Adjusted-R ${ }^{2}$ & 0.8964 & 0.8965 & 0.8965 & 0.8964 & 0.8965 \\
\hline Observations & 507 & & & & \\
\hline
\end{tabular}


Table 6. Abridged model results - truncated sample, excluding age

\begin{tabular}{|c|c|c|c|c|c|}
\hline & Incidents & Fatalities & Injuries & $\begin{array}{l}\text { Property } \\
\text { Damage }\end{array}$ & GTI \\
\hline Part A & $\begin{array}{c}\ln (\text { Life } \\
\text { satisfaction })\end{array}$ & $\begin{array}{c}\ln (\text { Life } \\
\text { satisfaction })\end{array}$ & $\begin{array}{c}\ln (\text { Life } \\
\text { satisfaction })\end{array}$ & $\begin{array}{c}\ln (\text { Life } \\
\text { satisfaction })\end{array}$ & $\begin{array}{c}\ln (\text { Life } \\
\text { satisfaction })\end{array}$ \\
\hline $\ln ($ Terrorism) (lag) & $\begin{array}{l}-0.0058^{*} \\
(0.0034)\end{array}$ & $\begin{array}{l}-0.0056^{*} \\
(0.0031)\end{array}$ & $\begin{array}{l}-0.0047^{*} \\
(0.0026)\end{array}$ & $\begin{array}{l}-0.0075^{*} \\
(0.0044)\end{array}$ & $\begin{array}{l}-0.0039^{*} \\
(0.0023)\end{array}$ \\
\hline Adjusted- $\mathrm{R}^{2}$ & 0.6399 & 0.6406 & 0.6404 & 0.6398 & 0.6401 \\
\hline Part B & $\begin{array}{c}\ln \text { (RGDP per } \\
\text { worker) }\end{array}$ & $\begin{array}{l}\ln \text { (RGDP per } \\
\text { worker) }\end{array}$ & $\begin{array}{c}\ln \text { (RGDP per } \\
\text { worker) }\end{array}$ & $\begin{array}{c}\ln \text { (RGDP per } \\
\text { worker) }\end{array}$ & $\begin{array}{c}\ln \text { (RGDP per } \\
\text { worker) }\end{array}$ \\
\hline $\ln ($ Terrorism) (lag) & $\begin{array}{l}-0.0119 \\
(0.0108)\end{array}$ & $\begin{array}{l}-0.0153 \\
(0.0097)\end{array}$ & $\begin{array}{l}-0.0130 \\
(0.0082)\end{array}$ & $\begin{array}{l}-0.0072 \\
(0.0139)\end{array}$ & $\begin{array}{l}-0.0092 \\
(0.0072)\end{array}$ \\
\hline Adjusted- $\mathrm{R}^{2}$ & 0.8962 & 0.8964 & 0.8964 & 0.8960 & 0.8962 \\
\hline Observations & 500 & & & & \\
\hline
\end{tabular}


Table 7. Abridged model results - full sample, excluding age

\begin{tabular}{|c|c|c|c|c|c|}
\hline & Incidents & Fatalities & Injuries & $\begin{array}{l}\text { Property } \\
\text { Damage }\end{array}$ & GTI \\
\hline Part A & $\begin{array}{c}\ln (\text { Life } \\
\text { satisfaction })\end{array}$ & $\begin{array}{c}\ln (\text { Life } \\
\text { satisfaction) }\end{array}$ & $\begin{array}{c}\ln (\text { Life } \\
\text { satisfaction) }\end{array}$ & $\begin{array}{c}\ln (\text { Life } \\
\text { satisfaction })\end{array}$ & $\begin{array}{c}\ln (\text { Life } \\
\text { satisfaction) }\end{array}$ \\
\hline \multirow[t]{2}{*}{$\ln ($ Terrorism) (lag) } & -0.0040 & $-0.0060^{*}$ & -0.0044 & -0.0050 & -0.0031 \\
\hline & $(0.0035)$ & $(0.0032)$ & $(0.0027)$ & $(0.0047)$ & $(0.0024)$ \\
\hline Adjusted-R ${ }^{2}$ & 0.5649 & 0.5666 & 0.5659 & 0.5647 & 0.5652 \\
\hline Part B & $\begin{array}{l}\ln (\text { RGDP per } \\
\text { worker })\end{array}$ & $\begin{array}{l}\ln (\text { RGDP per } \\
\text { worker })\end{array}$ & $\begin{array}{c}\ln (\text { RGDP per } \\
\text { worker })\end{array}$ & $\begin{array}{l}\ln (\text { RGDP per } \\
\text { worker })\end{array}$ & $\begin{array}{c}\ln (\text { RGDP per } \\
\text { worker })\end{array}$ \\
\hline \multirow[t]{2}{*}{$\ln ($ Terrorism) (lag) } & 0.0058 & 0.0027 & 0.00058 & 0.0082 & 0.0053 \\
\hline & $(0.0104)$ & $(0.0095)$ & $(0.0081)$ & $(0.0137)$ & $(0.0069)$ \\
\hline Adjusted-R ${ }^{2}$ & 0.8980 & 0.8980 & 0.8980 & 0.8980 & 0.8981 \\
\hline Observations & 621 & & & & \\
\hline
\end{tabular}


Table 8. Model results - truncated sample, OECD countries

\begin{tabular}{|c|c|c|c|c|c|}
\hline Part A & $\begin{array}{c}\text { Incidents } \\
\ln (\text { Life } \\
\text { satisfaction })\end{array}$ & $\begin{array}{c}\text { Fatalities } \\
\ln (\text { Life } \\
\text { satisfaction) }\end{array}$ & $\begin{array}{c}\text { Injuries } \\
\ln (\text { Life } \\
\text { satisfaction) }\end{array}$ & $\begin{array}{c}\text { Property Damage } \\
\ln (\text { Life } \\
\text { satisfaction })\end{array}$ & $\begin{array}{c}\text { GTI } \\
\ln (\text { Life } \\
\text { satisfaction })\end{array}$ \\
\hline $\ln ($ Age $)$ & $\begin{array}{c}-0.3166^{* * *} \\
(0.0680)\end{array}$ & $\begin{array}{c}-0.3535 * * * \\
(0.0727)\end{array}$ & $\begin{array}{c}-0.2848 * * * \\
(0.0701)\end{array}$ & $\begin{array}{c}-0.2814 * * * \\
(0.0670)\end{array}$ & $\begin{array}{c}-0.3123 * * * \\
(0.0684)\end{array}$ \\
\hline $\ln ($ RGDP per worker) & $\begin{array}{c}0.2125^{* * * *} \\
(0.0284)\end{array}$ & $\begin{array}{c}0.2217 * * * \\
(0.0291)\end{array}$ & $\begin{array}{c}0.2123 * * * \\
(0.0296)\end{array}$ & $\begin{array}{c}0.2044 * * * \\
(0.0285)\end{array}$ & $\begin{array}{c}0.2127 * * * \\
(0.0286)\end{array}$ \\
\hline $\ln$ (Human capital) & $\begin{array}{c}9.553 \mathrm{e}-04 \\
(0.0614)\end{array}$ & $\begin{array}{c}0.0175 \\
(0.0605)\end{array}$ & $\begin{array}{c}0.0350 \\
(0.0627)\end{array}$ & $\begin{array}{c}0.0148 \\
(0.0613)\end{array}$ & $\begin{array}{c}-2.662 \mathrm{e}-04 \\
(0.0620)\end{array}$ \\
\hline $\ln$ (Polity) & $\begin{array}{c}0.9355^{* * * *} \\
(0.2054)\end{array}$ & $\begin{array}{c}0.7050^{* * * *} \\
(0.2001)\end{array}$ & $\begin{array}{c}0.7431 * * * \\
(0.2056)\end{array}$ & $\begin{array}{c}0.9232 * * * \\
(0.2069)\end{array}$ & $\begin{array}{c}0.8880 * * * \\
(0.2039)\end{array}$ \\
\hline $\ln$ (Terrorism) (lag) & $\begin{array}{c}-0.0278 * * * \\
(0.0063)\end{array}$ & $\begin{array}{c}-0.0378 * * * \\
(0.0088)\end{array}$ & $\begin{array}{c}-0.0159 * * * \\
(0.0053)\end{array}$ & $\begin{array}{c}-0.0312 * * * \\
(0.0077)\end{array}$ & $\begin{array}{c}-0.0195 * * * \\
(0.0046)\end{array}$ \\
\hline Constant & $\begin{array}{c}-1.3872 * * * \\
(0.4103)\end{array}$ & $\begin{array}{c}-0.8762 * * \\
(0.4230)\end{array}$ & $\begin{array}{c}-1.1516 * * * \\
(0.4259)\end{array}$ & $\begin{array}{c}-1.4344 * * * \\
(0.4143)\end{array}$ & $\begin{array}{c}-1.2916^{* * *} \\
(0.4115)\end{array}$ \\
\hline Adjusted-R ${ }^{2}$ & 0.3980 & 0.3951 & 0.3612 & 0.3906 & 0.3947 \\
\hline Part B & $\begin{array}{l}\ln (\text { RGDP per } \\
\text { worker })\end{array}$ & $\begin{array}{l}\ln (\text { RGDP per } \\
\text { worker })\end{array}$ & $\begin{array}{l}\ln (\text { RGDP per } \\
\text { worker })\end{array}$ & $\begin{array}{l}\ln (\text { RGDP per } \\
\text { worker })\end{array}$ & $\begin{array}{l}\ln (\text { RGDP per } \\
\text { worker })\end{array}$ \\
\hline $\ln ($ Human capital) & $\begin{array}{l}-0.1191 \\
(0.1286)\end{array}$ & $\begin{array}{l}-0.0478 \\
(0.1228)\end{array}$ & $\begin{array}{l}-0.0844 \\
(0.1266)\end{array}$ & $\begin{array}{l}-0.1129 \\
(0.1271)\end{array}$ & $\begin{array}{l}-0.0875 \\
(0.1285)\end{array}$ \\
\hline $\ln$ (Capital stock per worker) & $\begin{array}{c}0.6193 * * * \\
(0.0423)\end{array}$ & $\begin{array}{c}0.6323 * * * \\
(0.0417)\end{array}$ & $\begin{array}{c}0.6182 * * * \\
(0.0420)\end{array}$ & $\begin{array}{c}0.6189 * * * \\
(0.0423)\end{array}$ & $\begin{array}{c}0.6212 * * * \\
(0.0422)\end{array}$ \\
\hline $\ln$ (Polity) & $\begin{array}{c}0.8293 * * \\
(0.3992)\end{array}$ & $\begin{array}{c}0.9577 * * \\
(0.3845)\end{array}$ & $\begin{array}{c}0.8824 * * \\
(0.3899)\end{array}$ & $\begin{array}{c}0.8086^{* *} \\
(0.4010)\end{array}$ & $\begin{array}{c}0.8049 * * \\
(0.3948)\end{array}$ \\
\hline $\ln$ (Terrorism) (lag) & $\begin{array}{c}0.0080 \\
(0.0124)\end{array}$ & $\begin{array}{c}0.0435 * * * \\
(0.0124)\end{array}$ & $\begin{array}{c}0.0149 \\
(0.0124)\end{array}$ & $\begin{array}{c}0.0128 \\
(0.0153)\end{array}$ & $\begin{array}{c}0.0114 \\
(0.0153)\end{array}$ \\
\hline Constant & $\begin{array}{l}1.9159 * * \\
(0.8252)\end{array}$ & $\begin{array}{c}1.2843 \\
(0.8392)\end{array}$ & $\begin{array}{l}1.7187 * * \\
(0.8306)\end{array}$ & $\begin{array}{l}1.9512 * * \\
(0.8256)\end{array}$ & $\begin{array}{l}1.8644 * * \\
(0.8228)\end{array}$ \\
\hline Adjusted-R ${ }^{2}$ & 0.6548 & 0.6701 & 0.6589 & 0.6555 & 0.6576 \\
\hline Observations & 152 & & & & \\
\hline
\end{tabular}


Table 9. Model results - truncated sample, non-OECD countries

\begin{tabular}{|c|c|c|c|c|c|}
\hline Part A & $\begin{array}{c}\text { Incidents } \\
\ln \text { (Life } \\
\text { satisfaction) }\end{array}$ & $\begin{array}{c}\text { Fatalities } \\
\ln \text { (Life } \\
\text { satisfaction) }\end{array}$ & $\begin{array}{c}\text { Injuries } \\
\ln \text { (Life } \\
\text { satisfaction) }\end{array}$ & $\begin{array}{c}\text { Property Damage } \\
\ln (\text { Life } \\
\text { satisfaction) }\end{array}$ & $\begin{array}{c}\text { GTI } \\
\ln \text { (Life } \\
\text { satisfaction) }\end{array}$ \\
\hline $\ln ($ Age $)$ & $\begin{array}{c}-0.1258 * * * \\
(0.0418)\end{array}$ & $\begin{array}{c}-0.1275^{* * *} \\
(0.0416)\end{array}$ & $\begin{array}{c}-0.1252 * * * \\
(0.0418)\end{array}$ & $\begin{array}{c}-0.1265 * * * \\
(0.0418)\end{array}$ & $\begin{array}{c}-0.1266^{* * *} \\
(0.0417)\end{array}$ \\
\hline $\ln$ (RGDP per worker) & $\begin{array}{c}0.1584 * * * \\
(0.0110)\end{array}$ & $\begin{array}{c}0.1583 * * * \\
(0.0109)\end{array}$ & $\begin{array}{c}0.1581 * * * \\
(0.0109)\end{array}$ & $\begin{array}{c}0.1587 * * * \\
(0.0109)\end{array}$ & $\begin{array}{c}0.1582 * * * \\
(0.0109)\end{array}$ \\
\hline $\ln$ (Human capital) & $\begin{array}{c}-0.0491 * * \\
(0.0242)\end{array}$ & $\begin{array}{c}-0.0496 * * \\
(0.0242)\end{array}$ & $\begin{array}{c}-0.0489 * * \\
(0.0242)\end{array}$ & $\begin{array}{c}-0.0489 * * \\
(0.0242)\end{array}$ & $\begin{array}{c}-0.0492 * * \\
(0.0242)\end{array}$ \\
\hline $\ln$ (Polity) & $\begin{array}{c}0.0623 * * * \\
(0.0143)\end{array}$ & $\begin{array}{c}0.0619 * * * \\
(0.0143)\end{array}$ & $\begin{array}{c}0.0618 * * * \\
(0.0141)\end{array}$ & $\begin{array}{c}0.0624 * * * \\
(0.0143)\end{array}$ & $\begin{array}{c}0.0619 * * * \\
(0.0143)\end{array}$ \\
\hline $\ln ($ Terrorism) (lag) & $\begin{array}{l}-0.0019 \\
(0.0040)\end{array}$ & $\begin{array}{l}-0.0025 \\
(0.0034)\end{array}$ & $\begin{array}{l}-0.0018 \\
(0.0030)\end{array}$ & $\begin{array}{l}-0.0020 \\
(0.0052)\end{array}$ & $\begin{array}{l}-0.0018 \\
(0.0026)\end{array}$ \\
\hline Constant & $\begin{array}{c}0.5234 * * * \\
(0.0966)\end{array}$ & $\begin{array}{c}0.5323 * * * \\
(0.0974)\end{array}$ & $\begin{array}{c}0.5249 * * * \\
(0.0966)\end{array}$ & $\begin{array}{c}0.5209 * * * \\
(0.0965)\end{array}$ & $\begin{array}{c}0.5310 * * * \\
(0.0974)\end{array}$ \\
\hline Adjusted-R ${ }^{2}$ & 0.4596 & 0.4601 & 0.4599 & 0.4592 & 0.4601 \\
\hline Part B & $\begin{array}{l}\ln (\text { RGDP per } \\
\text { worker) }\end{array}$ & $\begin{array}{l}\ln (\text { RGDP per } \\
\text { worker) }\end{array}$ & $\begin{array}{l}\ln (\text { RGDP per } \\
\text { worker) }\end{array}$ & $\begin{array}{l}\ln (\text { RGDP per } \\
\text { worker) }\end{array}$ & $\begin{array}{c}\ln (\text { RGDP per } \\
\text { worker })\end{array}$ \\
\hline $\ln ($ Human capital) & $\begin{array}{c}0.5104 * * * \\
(0.0677)\end{array}$ & $\begin{array}{c}0.5083 * * * \\
(0.0680)\end{array}$ & $\begin{array}{c}0.5148 * * * \\
(0.0675)\end{array}$ & $\begin{array}{c}0.5159 * * * \\
(0.0678)\end{array}$ & $\begin{array}{c}0.5072 * * * \\
(0.0677)\end{array}$ \\
\hline $\ln$ (Capital stock per worker) & $\begin{array}{c}0.6403 * * * \\
(0.0245)\end{array}$ & $\begin{array}{c}0.6394 * * * \\
(0.0245)\end{array}$ & $\begin{array}{c}0.6395^{* * * *} \\
(0.0245)\end{array}$ & $\begin{array}{c}0.6416 * * * \\
(0.0246)\end{array}$ & $\begin{array}{c}0.6384 * * * \\
(0.0245)\end{array}$ \\
\hline $\ln$ (Polity) & $\begin{array}{c}-0.1108 * * \\
(0.0437)\end{array}$ & $\begin{array}{c}-0.1180 * * * \\
(0.0436)\end{array}$ & $\begin{array}{c}-0.1165 * * * \\
(0.0435)\end{array}$ & $\begin{array}{c}-0.1122 * * \\
(0.0439)\end{array}$ & $\begin{array}{c}-0.1173 * * * \\
(0.0435)\end{array}$ \\
\hline $\ln$ (Terrorism) (lag) & $\begin{array}{c}-0.0254^{* *} \\
(0.0129)\end{array}$ & $\begin{array}{l}-0.0177 \\
(0.0110)\end{array}$ & $\begin{array}{c}-0.0192 * * \\
(0.0097)\end{array}$ & $\begin{array}{l}-0.0208 \\
(0.0169)\end{array}$ & $\begin{array}{c}-0.0187 * * \\
(0.0086)\end{array}$ \\
\hline Constant & $\begin{array}{c}1.9825^{* * *} \\
(0.2229)\end{array}$ & $\begin{array}{c}2.0064 * * * \\
(0.2258)\end{array}$ & $\begin{array}{c}1.9935 * * * \\
(0.2234)\end{array}$ & $\begin{array}{c}1.9462 * * * \\
(0.2228)\end{array}$ & $\begin{array}{c}2.0325 * * * \\
(0.2254)\end{array}$ \\
\hline Adjusted-R ${ }^{2}$ & 0.8487 & 0.8482 & 0.8487 & 0.8477 & 0.8491 \\
\hline Observations & 348 & & & & \\
\hline
\end{tabular}




\section{Appendix $A$}

Table A1. OLS and tobit estimates, truncated sample, GTI

\begin{tabular}{lcc}
\hline & OLS & Tobit model \\
& $\ln ($ Life satisfaction) & $\ln ($ Life satisfaction) \\
\hline $\ln$ (Age) & $-0.1084^{* *}$ & $-0.0729 * *$ \\
& $(0.0359)$ & $(0.0365)$ \\
$\ln$ (RGDP per worker) & $0.1734^{* * *}$ & $0.1543^{* * *}$ \\
& $(0.0092)$ & $(0.0093)$ \\
$\ln ($ Human capital) & $-0.0578^{* *}$ & -0.0356 \\
& $(0.0217)$ & $(0.0218)$ \\
$\ln ($ Polity) & $0.0805^{* * *}$ & $0.0754^{* * *}$ \\
& $(0.0128)$ & $(0.0128)$ \\
$\ln$ (Terrorism) (lag) & $-0.0039^{*}$ & $-0.0040^{*}$ \\
& $(0.0023)$ & $(0.0023)$ \\
Constant & $0.3315^{* * *}$ & $0.3660^{* * *}$ \\
& $(0.0700)$ & $(0.0704)$ \\
Year fixed effects & Yes & Yes \\
Adjusted-R & 0.6416 & - \\
Observations & 500 & 500 \\
\hline
\end{tabular}

Standard errors in parentheses

${ }^{* * *} \mathrm{p}<0.01,{ }^{* *} \mathrm{p}<0.05,{ }^{*} \mathrm{p}<0.1$ 


\section{Appendix $B$}

Countries included in analysis:

Albania; Argentina; Australia; Austria; Bangladesh; Belgium; Benin; Bolivia; Botswana; Brazil; Bulgaria; Cambodia; Cameroon; Canada; Central African Republic; Chile; China; Colombia; Costa Rica; Cote d'Ivoire; Croatia; Cyprus; Czech Republic; Democratic Republic of the Congo; Denmark; Dominican Republic; Ecuador; Egypt; El Salvador; Estonia; France; Gabon; Germany; Ghana; Greece; Guatemala; Honduras; Hungary; Iceland; India; Indonesia; Iran; Iraq; Ireland; Israel; Italy; Jamaica; Japan; Jordan; Kazakhstan; Kenya; Kuwait; Kyrgyz Republic; Laos; Latvia; Liberia; Lithuania; Malawi; Malaysia; Mali; Mauritania; Mauritius; Mexico; Moldova; Mongolia; Morocco; Mozambique; Namibia; Nepal; Netherlands; New Zealand; Niger; Norway; Pakistan; Panama; Paraguay; Peru; Philippines; Poland; Portugal; Qatar; Republic of the Congo; Romania; Russia; Rwanda; Saudi Arabia; Senegal; Serbia; Sierra Leone; Singapore; Slovakia; Slovenia; South Africa; South Korea; Spain; Sri Lanka; Sudan; Sweden; Switzerland; Syria; Taiwan; Tajikistan; Tanzania; Thailand; Togo; Trinidad and Tobago; Tunisia; Turkey; Uganda; Ukraine; United Kingdom; United States of America; Uruguay; Venezuela; Vietnam; Yemen; Zambia; Zimbabwe.

Countries with no terrorist attacks between 2006 and 2011:

Botswana; Costa Rica; Dominican Republic; El Salvador; Estonia; Gabon; Ghana; Iceland; Jamaica; Laos; Latvia; Liberia; Lithuania; Malawi; Mauritius; Mongolia; Namibia; Poland; Portugal; Republic of the Congo; Sierra Leone; Singapore; Slovakia; Slovenia; Togo; Vietnam; Zambia.

OECD members in truncated sample:

Australia; Austria; Belgium; Canada; Chile; Czech Republic; Denmark; Finland; France; Germany; Greece; Hungary; Ireland; Israel; Italy; Japan; Mexico; Netherlands; New Zealand; Norway; South Korea; Spain; Sweden; Switzerland; Turkey; United Kingdom; United States of America. 


\section{Appendix C}

Table C1. Pairwise correlations

\begin{tabular}{|c|c|c|c|c|c|c|c|c|c|c|c|}
\hline & $\begin{array}{l}\text { Life } \\
\text { satisfaction }\end{array}$ & $\begin{array}{l}\text { Incidents } \\
\text { (lag) }\end{array}$ & $\begin{array}{l}\text { Fatalities } \\
\text { (lag) }\end{array}$ & $\begin{array}{l}\text { Injuries } \\
\text { (lag) }\end{array}$ & $\begin{array}{l}\text { Property } \\
\text { damage } \\
\text { (lag) }\end{array}$ & $\begin{array}{l}\text { Index } \\
\text { (lag) }\end{array}$ & $\begin{array}{l}\text { RGDP } \\
\text { per } \\
\text { worker }\end{array}$ & $\begin{array}{l}\text { Capital } \\
\text { stock } \\
\text { per } \\
\text { worker }\end{array}$ & $\begin{array}{l}\text { Human } \\
\text { capital }\end{array}$ & Age & Polity4 \\
\hline Incidents (lag) & -0.1605 & 1 & & & & & & & & & \\
\hline $\begin{array}{l}\text { Property } \\
\text { damage (lag) }\end{array}$ & -0.1412 & 0.9717 & 0.9250 & 0.9178 & 1 & & & & & & \\
\hline Index (lag) & -0.1734 & 0.9794 & 0.9941 & 0.9815 & 0.9468 & 1 & & & & & \\
\hline $\begin{array}{l}\text { RGDP per } \\
\text { worker }\end{array}$ & 0.6780 & -0.1444 & -0.1599 & -0.1287 & -0.1219 & -0.1490 & 1 & & & & \\
\hline Polity4 & 0.3361 & -0.0703 & -0.0747 & -0.0660 & -0.0584 & -0.0717 & 0.1645 & 0.1505 & 0.4315 & 0.4704 & 1 \\
\hline
\end{tabular}




\section{Notes}

1. Alex Weingrod, "How Israeli Culture Was Constructed: Memory, History and the Israeli Past," Israel Studies 2, no. 1 (1997): 228-237.

2. Alfred Cobban, "The Political Ideas of Maximilien Robespierre During the Period of the Convention," English Historical Review 61, no. 239 (1946): 57.

3. Davydd Greenwood, "Castilians, Basques, and Andalusians: An Historical Comparison of Nationalism,'True' Ethnicity, and 'False' Ethnicity," in Paul Brass (eds.), Ethnic Groups and the State (New Jersey: Barnes and Noble, 1985), 202-227.

4. John Horgan and Max Taylor, "The Provisional Irish Republican Army: Command and Functional Structure," Terrorism and Political Violence 9, no. 3 (1997): 1-32.

5. Peter Ekeh, "Colonialism and the Two Publics in Africa: A Theoretical Statement," Comparative Studies in Society and History 17, no. 1 (1975): 91112; Frederick Cooper, "Conflict and Connection: Rethinking Colonial African History," The American Historical Review 99, no. 5 (1994): 15161545.

6. Henry Steelman, "International Terrorism Vis-a-Vis Air-Hijacking," Southwestern University Law Review 9, no. 1 (1977): 85-110.

7. Simon Reeve, One Day in September: The Full Story of the 1972 Munich Olympics Massacre and the Israeli Revenge Operation" Wrath of God": With a New Epilogue (New York: Arcade Publishing, 2011). 
8. Mark Schuster et al., "A National Survey of Stress Reactions after the September 11, 2001, Terrorist Attacks," New England Journal of Medicine 345, no. 20 (2001): 1507-1512.

9. ABS, "Australian Social Trends," (Canberra, 1995).

10. Institute for Economics and Peace, "Global Terrorism Index: Capturing the Impact of Terrorism for the Last Decade," (New York, 2012).

11. "Global Peace Index: Measuring Peace and Assessing Country Risk," (New York, 2014). The other three indicators are: number of internal and external conflicts fought; number of displaced people as a percentage of the population; and number of deaths from organized internal conflict.

12. Walter Enders and Todd Sandler, "Economic Consequences of Terrorism in Developed and Developing Countries: An Overview," in Philip Keefer and Norman Loayza (eds.), Terrorism, Economic Development, and Political Openness (Cambridge, UK: Cambridge University Press, 2008), 17-47; S. Brock Blomberg, Gregory D. Hess, and Athanasios Orphanides, "The Macroeconomic Consequences of Terrorism," Journal of Monetary Economics 51, no. 5 (2004): 1007-1032; S. Brock Blomberg, Gregory D. Hess, and Akila Weerapana, "Economic Conditions and Terrorism," European Journal of Political Economy 20 (2004): 463-478.

13. Blomberg, Hess, and Orphanides, "The Macroeconomic Consequences of Terrorism," (see note 12 above); Blomberg, Hess, and Weerapana, "Economic Conditions and Terrorism,"(see note 12 above). 
14. Jose Tavares, "The Open Society Assesses Its Enemies: Shocks, Disasters and Terrorist Attacks," Journal of Monetary Economics 51, no. 5 (2004): 10391070.

15. Khusrav Gaibulloev and Todd Sandler, "Growth Consequences of Terrorism in Western Europe," Kyklos 61, no. 3 (2008): 411-424; Khusrav Gaibulloev and Todd Sandler,"The Adverse Effect of Transnational and Domestic Terrorism on Growth in Africa," Journal of Peace Research 48 (2011): 355371; Khusrav Gaibulloev and Todd Sandler, "The Impact of Terrorism and Conflicts on Growth in Asia," Economics \& Politics 21, no. 3 (2009): 359383.

16. Alberto Abadie and Javier Gardeazabal, "The Economic Costs of Conflict: A Case-Control Study for the Basque Country " American Economic Review 93, no. 1 (2003): 113-132.

17. Zvi Eckstein and Daniel Tsiddon, "Macroeconomic Consequences of Terror: Theory and the Case of Israel," Journal of Monetary Economics 51, no. 5 (2004): 971-1002.

18. David Fielding, "Counting the Cost of the Intifada: Consumption, Saving and Political Instability in Israel " Public Choice 116, no. 3/4 (2003): 297-312.

19. Eckstein and Tsiddon (see note 17 above).

20. Bruno S. Frey, Simon Luechinger, and Alois Stutzer, "Calculating Tragedy: Assessing the Costs of Terrorism," Journal of Economic Surveys 21, no. 1 (2007): 1-24.

21. Ibid. 
22. Paul Collier, "On the Economic Consequences of Civil War," Oxford Economic Papers 51, no. 1 (1999): 168-183.

23. David Fielding, "Modelling Political Instability and Economic Performance: Israeli Investment During the Intifada," Economica 70, no. 277 (2003): 159186.

24. Frey, Luechinger, and Stutzer, "Calculating Tragedy: Assessing the Costs of Terrorism," (see note 20 above).

25. Alberto Abadie and Javier Gardeazabal, "The Economic Costs of Conflict: A Case-Control Study for the Basque Country," The American Economic Review 93 (2003): 113-132.

26. Rafi Eldor and Rafi Melnick, "Financial Markets and Terrorism," European Journal of Political Economy 20, no. 2 (2004): 367-386.

27. Konstantinos Drakos, "Terrorism Activity, Investor Sentiment, and Stock Returns," Review of Financial Economics 19, no. 3 (2010): 128-135.

28. Naceur Essaddam and John Karagianis, "Terrorism, Country Attributes, and the Volatility of Stock Returns," Research in International Business and Finance 31 (2014): 87-100.

29. Walter Enders and Todd Sandler, "Terrorism and Foreign Direct Investment in Spain and Greece," Kyklos 49, no. 3 (1996): 331-352.

30. For a formal exposition of this argument see Alberto Abadie and Javier Gardeazabal, "Terrorism and the World Economy," European Economic Review 52, no. 1 (2008): 1-27. 
31. Volker Nitsch and Dieter Schumacher, "Terrorism and International Trade: An Empirical Investigation," European Journal of Political Economy 20, no. 2 (2004): 423-433.

32. Daniel Mirza and Thierry Verdier, "International Trade, Security and Transnational Terrorism: Theory and a Survey of Empirics," Journal of Comparative Economics 36, no. 2 (2008): 179-194.

33. Frey, Luechinger, and Stutzer, "Calculating Tragedy: Assessing the Costs of Terrorism" (see note 20 above).

34. Jose M. Salguero et al., "Trajectory and Predictors of Depression in a 12Month Prospective Study after the Madrid March 11 Terrorist Attacks," Journal of Psychiatric Research 45, no. 10 (2011): 1395-1403.

35. Roxane C. Silver et al., "Nationwide Longitudinal Study of Psychological Responses to September 11," The Journal of the American Medical Association 288, no. 10 (2002): 1235-1244; Schuster et al. (see note 8 above); Sandro Galea et al., "Psychological Sequelae of the September 11 Terrorist Attacks in New York City," New England Journal of Medicine 346, no. 13 (2002): 982-987; William Schlenger et al., "Psychological Reactions to Terrorist Attacks: Findings from the National Study of Americans' Reactions to September 11," The Journal of the American Medical Association 288, no. 5 (2002): 581-588.

36. Roxane C. Silver et al., "Nationwide Longitudinal Study of Psychological Responses to September 11," The Journal of the American Medical Association 288, no. 10 (2002): 1235-1244.

37. Schuster et al. (see note 8 above); Schlenger et al. (see note 35 above). 
38. Silver et al. (see note 36 above).

39. G. James Rubin et al., "Psychological and Behavioural Reactions to the Bombings in London on 7 July 2005: Cross Sectional Survey of a Representative Sample of Londoners," British Medical Journal 331, no. 7517 (2005): 606-611.

40. Salguero et al. (see note 34 above).

41. Avi Bleich, Marc Gelkopf, and Zahava Solomon, "Exposure to Terrorism, Stress-Related Mental Health Symptoms, and Coping Behaviors among a Nationally Representative Sample in Israel," The Journal of the American Medical Association 290, no. 5 (2003): 612-620.

42. Avi Bleich et al., "Mental Health and Resiliency Following 44 Months of Terrorism: A Survey of an Israeli National Representative Sample," $B M C$ Medicine 4, no. 21 (2006): 1-11.

43. Alex Braithwaite, "The Logic of Public Fear in Terrorism and CounterTerrorism," Journal of Police and Criminal Psychology 28, no. 2 (2013): 95101.

44. Ibid.

45. Bruno S. Frey, Simon Luechinger, and Alois Stutzer, "The Life Satisfaction Approach to Valuing Public Goods: The Case of Terrorism," Public Choice 138, no. 3/4 (2009): 317-345.

46. Dmitri Romanov, Asaf Zussman, and Noam Zussman, "Does Terrorism Demoralize? Evidence from Israel," Economica 79, no. 313 (2012): 183-198. 
47. Robert Metcalfe, Nattavudh Powdthavee, and Paul Dolan, "Destruction and Distress: Using a Quasi-Experiment to Show the Effects of the September 11 Attacks on Mental Well-Being in the United Kingdom," The Economic Journal 121, no. 550 (2011): F81-F103.

48. S. Brock Blomberg, Gregory D. Hess, and Daniel Y. J. Tan, "Terrorism and the Economics of Trust," Journal of Peace Research 48, no. 3 (2011): 383398.

49. Bruno S. Frey and Alois Stutzer, Happiness and Economics: How the Economy and Institutions Affect Human Well-Being (Princeton, NJ: Princeton University Press, 2002); "What Can Economists Learn from Happiness Research?," Journal of Economic Literature 40, no. 2 (2002): 402-435.

50. Richard E. Lucas and M. Brent Donnellan, "Estimating the Reliability of Single-Item Life Satisfaction Measures: Results from Four National Panel Studies," Social Indicators Research 105, no. 3 (2012): 232-331; Ed Diener, Ronald Inglehart, and Louis Tay, "Theory and Validity of Life Satisfaction Scales," Social Indicators Research 112, no. 3 (2013): 497-527.

51. Heinz Welsch, "The Welfare Costs of Corruption," Applied Economics 40, no. 14 (2008): 1839-1849.

52. Robert E. Hall and Charles I. Jones, "Why Do Some Countries Produce So Much More Output Per Worker Than Others?," The Quarterly Journal of Economics 114, no. 1 (1999): 83-116.

53. Welsch (see note 51 above). 
54. Rather than employing the current period measure of terrorism, the one-year lagged is used. As terrorist incidents occur all year round, the lagged variable makes a causal interpretation plausible.

55. Welsch (see note 51 above).

56. Ada Ferrer-i-Carbonell and Paul Frijters, "How Important Is Methodology for the Estimates of the Determinants of Happiness?," The Economic Journal 114, no. 497 (2004): 641-659.

57. Daniel Kahneman, "Objective Happiness," in Daneil Kahneman, Edward Diener, and Norbert Schwarz (eds.), Well-Being: The Foundations of Hedonic Psychology (New York: Russell Sage Foundation, 1999), 3-25.

58. Ruut Veenhoven, "World Database of Happiness - Average Happiness in 149 Nations 2000-2009," worlddatabaseofhappiness.eur.nl/hap_nat/findingreports/RankReport_Average Happiness.php (accessed May 4, 2014)

59. Global Terrorism Database (GTD), http://www.start.umd.edu/gtd/ (accessed September 12, 2014).

60. Institute for Economics and Peace, "Global Terrorism Index: Measuring and Understanding the Impact of Terrorism," (New York, 2014).

61. Joe Eyerman, "Terrorism and Democratic States: Soft Targets or Accessible Systems," International Interactions 24, no. 2 (1998): 151-170; Quan Li, "Does Democracy Promote or Reduce Transnational Terrorist Incidents?," Journal of Conflict Resolution 49, no. 2 (2005): 278-297; Alberto Abadie, "Poverty, Political Freedom and the Roots of Terrorism," The American Economic Review 96 (2006): 50-56; Krisztina Kis-Katos, Helge Liebert, and 
Gunther G. Schulze, "On the Origin of Domestic and International Terrorism," European Journal of Political Economy 27, no. 1 (2011): S17-S36.

62. Abadie (see note 61 above); Peter Kurrild-Klitgaard, Mogens K. Justesen, and Robert Klemmensen, "The Political Economy of Freedom, Democracy and Transnational Terrorism," Public Choice 128, no. 1-2 (2006): 289-315; Eyerman (see note 61 above).

63. Joseph Stiglitz, Amartya Sen, and Jean-Paul Fitoussi, "Report by the Commission on the Measurement of Economic Performance and Social Progress," (Paris, 2009). p. 16.

64. Andrew H. Chen and Thomas F. Siems, "The Effects of Terrorism on Global Capital Markets," European Journal of Political Economy 20, no. 2 (2004): 249-266; Enders and Sandler, "Economic Consequences of Terrorism in Developed and Developing Countries: An Overview" (see note 12 above).

65. Chen and Siems (see note 64 above).

66. Tavares (see note 14 above).

67. Blomberg, Hess, and Orphanides, "The Macroeconomic Consequences of Terrorism," (see note 12 above).

68. Global Terrorism Database (GTD), http://www.start.umd.edu/gtd/ (accessed September 12, 2014).

69. Bleich et al. (see note 42 above)

70. Gary S. Becker and Yona Rubinstein, "Fear and the Response to Terrorism: An Economic Analysis." Centre for Economic Performance, Discussion Paper no. 1079 (2011). 
71. Gerd Gigerenzer, "Dread Risk, September 11, and Fatal Traffic Accidents ". Psychological Science 15, no. 24 (2004): 286-287.

72. Christopher Ambrey, Christopher Fleming, Matthew Manning, and Christine Smith, "On the confluence of freedom of the press, control of corruption and societal welfare". Social Indicators Research (in press - accepted 24 July 2015).

73. Ruut Veenhoven, "Cross-national differences in happiness: Cultural measurement bias or effect of culture?". International Journal of Wellbeing 2, no. 4 (2012): 333-353.

74. Global Terrorism Database (GTD), (see note 59 above). 1993 data were lost in an office move and have never been fully recovered.

75. Veenhoven (see note 58 above).

76. Institute for Economics and Peace (see note 60 above).

77. Ibid.

78. Ibid.

79. Ibid.

80. Ibid.

81. Robert Feenstra, Robert Inklaar, and Marcel Timmer, "The Next Generation of the Penn World Table," www.ggdc.net/pwt (accessed May 4, 2014)

82. Ibid.

83. Ibid.

84. Monty G. Marshall, "Polity IV Project," http://www.systemicpeace.org/polity/polity4.htm (accessed May 4, 2014) 
85. UNESCO Institute for Statistics,

http://data.uis.unesco.org/Index.aspx?DataSetCode=SCN DS (accessed May $4,2014)$ 